\title{
Wither Social Citizenship? Lived Experiences of Citizenship In/Exclusion for Recipients of Out-of-Work Benefits
}

\section{Ruth Patrick}

School of Law and Social Justice, University of Liverpool

E-mail: Ruth.Patrick@liverpool.ac.uk

Drawing on a qualitative longitudinal study that examined experiences of welfare reform among a small group of recipients of out-of-work benefits, this paper considers how individuals' social citizenship rights, responsibilities and status are all affected by processes of welfare reform. It discusses the ways in which welfare conditionality impacts upon targeted individuals' citizenship status, noting a trend towards 'conditioning', where people seek to govern and manage their own behaviour(s) in order to meet the demands of contemporary citizenship. The paper considers the extent to which even a 'modicum of economic welfare and security' is now denied to so many Britons, concluding with a discussion of what if any emancipatory potential social citizenship still holds.

Keywords: Social citizenship, welfare reform, security, conditionality.

\section{Introduction}

Setting out his UK Government's ambitions to improve life chances, then Prime Minister David Cameron declared:

this government is all about security ... security is ... what drives the social reform that I want this government to undertake in my second term. Individuals and families who are in poverty crave security - for them, it's the most important value of all. (Cameron, 2016)

Almost seventy years earlier, the classic liberal citizenship theorist, T. H. Marshall, described the importance of providing social rights to citizens such that they are able to enjoy at least a 'modicum of economic welfare and security' (Marshall, 1950: 8). Successive waves of welfare reform from the 1980s onwards dismantled and fractured social rights established in the post-war period, with citizenship increasingly mobilised as a tool of governance to enforce state-defined responsible behaviour (principally participation in the paid labour market) (Dwyer, 2010; Lister, 2011; Dwyer and Wright, 2014). Today, egalitarian ideals of social citizenship appear increasingly under threat, especially given the downgrading of the social and economic protection, the 'security', which social rights now provide.

Critically, the welfare reforms of Cameron and his predecessors are fundamentally reworking and reimaging the nature and role of social citizenship, with potentially farreaching consequences. Set against this context, it is critical to explore how those in receipt of out-of-work benefits experience and respond to welfare reform, and how these experiences affect their citizenship status and sense of in/exclusion within the wider citizenry: the focus of this article. Following an introduction to the theoretical and 
political context, and the research study itself, this paper explores how social citizenship is experienced by those living with poverty and welfare reform.

\section{Social citizenship as theoretical lens}

Social citizenship is fundamentally about inclusion and exclusion, about who is and who is not included in the citizenry and on what basis (Lister, 2003; Dwyer, 2010). It focuses attention on questions of membership and belonging, rights and responsibilities, what is expected for those granted the status of citizen, and what can be expected from them in return. In seeking to better understand experiences of welfare reform, social citizenship can serve as a valuable theoretical lens to direct attention to whether and how reforms affect both the citizenship in/exclusion of those directly affected and the level of security and protection provided by social rights.

While republican theories of citizenship focus on citizenship as a practice, which brings with it particular obligations and expectations concerning how to live the life of a 'good citizen', liberal theories conceive of citizenship as a status, to which is attached a bundle of rights and responsibilities (Dwyer, 2010). In this article, both liberal and republican understandings of citizenship are drawn upon in tandem, reflecting the ways in which recent governments' articulations of citizenship adopt both approaches to describe not only the rights and responsibilities, but also the expected practice(s) of citizens (Patrick, 2015). Political pronouncements frequently draw upon contractual, liberal ideas of citizenship as a status, which brings with it particular rights and responsibilities, with work-related conditionality a policy approach which explicitly ties the 'right' to state support to the responsibility to take steps to return to paid employment (Crabb, 2016, cf. Cameron, 2011). At the same time, there is often an associated and underlying emphasis on republican notions of citizenship as a practice, here narrowly conceived as engagement with and participation in the formal labour market (Patrick, 2015).

In theorising social citizenship, it is valuable to draw a distinction between citizenship as it is constructed and articulated from above, and citizenship as it is lived and experienced from below, a distinction which is also sometimes conceptualised as between top-down and bottom-up approaches to citizenship (Lister, 2003; Clarke et al., 2014). This directs analytical attention to how dominant political narratives conceptualise and operate ideas and ideals of social citizenship as well as to how this dominant narrative is experienced in the 'everyday world' of citizenship (Desforges et al., 2005, cited in Lister, 2007: 58). There is particular scope to explore the extent of any disjuncture between conceptualisations from above and below (Patrick, 2015), in an effort to better understand what Duffy (2016) describes as 'everyday citizenship'.

\section{Social citizenship from above}

The dominant citizenship narrative from above situates engagement in paid employment as the marker of the dutiful, responsible citizen (Lister, 2011; Dwyer and Wright, 2014). In defending welfare reforms that make social welfare eligibility increasingly conditional on taking steps to prepare for and enter the labour market, successive governments have argued that such reforms will deliver 'social inclusion' by supporting targeted individuals to become responsible, hard-working citizens (Levitas, 1998). In recent years, we have witnessed a substantive ratcheting up of welfare conditionality, which sits alongside 
measures in the Welfare Reform Act 2012 that reduce real levels of benefits (via changes to uprating rules), restrict eligibility (via changes to disability and housing benefits) as well as in some cases severing the link between need and entitlement (most notably, in the case of the Benefits Cap) (DWP, 2012; Dwyer and Wright, 2014). Welfare conditionality has been both intensified and extended (McKay and Rowlingson, 2011), such that it is now applied to many single parents and disabled people as well as to the traditional target group of jobseekers. Today, sanctions for non-compliance include the 'ultimate' sanction of three years without benefits for those who three times fail to fulfil the most serious of the work-related conditions (for a summary of recent welfare reforms see De Agostini et al., 2015; Beatty and Fothergill, 2016).

During Cameron's time in office, these welfare reforms have been justified on the basis of the need to deliver 'fairness' in the benefits system, and to reinvigorate social citizenship by ensuring that there is an equitable contract between those who receive social welfare support, and those who fund it through the taxation system (Osborne, 2010). Here, there is a shift from viewing the core relationship as between the state and its citizens to a crude focus on the obligations which the 'hard-working majority' can reasonably demand from 'welfare dependants'. In this account, we can begin to see the unpicking of assumptions about the equal treatment and status of all citizens and instead the construction of differentiated contractual relationships both between individuals and the state, but crucially also among sub-groups of citizens. In this way, those in receipt of out-of-work benefits start to be seen as having responsibilities not just to the state, but also to their fellow citizens; those characterised as hard-working taxpayers whose engagement in paid employment funds out-of-work benefit recipients. These differentiated contractual relationships can extend the exclusionary potential of social citizenship, as well as increasing the scope for tensions between and among citizens.

At the same time, we have also seen what the Conservatives describe as a new approach to poverty (DWP and Department for Education, 2011), which focuses much less on income measurements and fiscal redistribution, and concentrates instead on addressing what are described as the behavioural pathways to poverty. Notably, one of the presumed pathways to poverty (which sit alongside family breakup, addiction, debt and poor educational attainment) is worklessness (DWP and Department for Education, 2011), meaning that the policy response to poverty becomes predicated upon the welfare-towork effort, a focus that is retained despite the persistence of widespread in-work poverty. In this way, narratives of citizenship, poverty and welfare reform are closely intertwined, all rooted in a valorisation of 'work', which is conceptualised as bringing with it societal inclusion and financial rewards - premises that are often undermined by lived experiences of poverty and paid employment (Bailey, 2016; Shildrick et al., 2012).

\section{The lived experiences of welfare reform study}

In seeking to understand how the dominant citizenship narrative is experienced from below, this article presents findings from a qualitative longitudinal study that explored the lived experiences of welfare reform. In qualitative longitudinal research, time becomes both a vehicle and object of study (Henwood et al., 2012), and there was invaluable scope in this instance to track both the presence and absence of change as welfare reforms took effect. Working with two gatekeeper organisations and employing purposive sampling, an initial sample of twenty-two individuals were interviewed in 2011, all of whom were 
affected by welfare reforms introduced by the 2010-15 Westminster Coalition. The sample was selected to include twelve disabled people being migrated from Incapacity Benefit onto Employment and Support Allowance, five single parents affected by a lowering of the age of youngest child at which parents are migrated from Income Support onto Jobseeker's Allowance (JSA), and five young jobseekers engaging with the reformed conditionality and sanctions regime.

The study was based in Leeds, a post-industrial city with areas of high deprivation as well as areas of considerable wealth. Of the twenty-two participants initially interviewed, a smaller sample of fifteen was selected to follow longitudinally on the basis of those most likely to experience welfare reforms during the research period. These fifteen were interviewed a further two times between 2011 and 2013. Of the fifteen followed over time, contact was lost with just one participant between the second and third interviews. Ethical approval for the study was granted by the University of Leeds. Anonymity and informed consent were prioritised, with a 'refresh and remind' approach taken such that consent was re-sought at each new research encounter, when the key elements of the study were re-introduced (Neale and Hanna, 2012). Further, the study featured participatory elements, including the Dole Animators film project (see Dole Animators, 2013). The commitment to including a participatory dimension was seen as an ethical decision that was tied to ensuring that some of the outputs from the study had meaning and relevance for the participants themselves. The interview data were analysed thematically and by cases, with cross-sectional analysis of overarching themes, and longitudinal analysis of individual participants, as well as an analysis of the iteration between the two. The research generated rich, thick description regarding lived experiences of welfare reform - it is to a discussion of these findings that this article now turns.

\section{Social rights of citizenship re-examined}

T. H. Marshall defined the social rights of citizenship in both maximalist and minimalist terms as:

the whole range [of social rights] from the right to a modicum of economic welfare and security, to the right to share to the full in the social heritage and to live the civilized life according to the standards prevailing in society. (Marshall, 1950: 8)

In this study, it was possible to explore what 'getting by' on benefits entailed and the social rights provided to those in receipt of out-of-work benefits. What was particularly notable was the extent to which those living on out-of-work benefits were forced to actively manage on very low-incomes. 'Going without' and having to make difficult choices (such as to heat or eat) were very common, something which is frequently found in the wider empirical research evidence (Daly and Kelly, 2015; Lansley and Mack, 2015). A narrative of going without and making do was a central theme of the interviews undertaken (Patrick, 2015). As Cath reported:

[earlier] this year I needed underwear so I didn't pay my gas and electric that fortnight. And I spent it on underwear. (Cath, $\mathrm{W} 1^{1}$ ) 
The parents in the study frequently spoke of going without so that their children could be well cared for, and there were also instances of participants shoplifting for basic necessities.

A few week ago, I only had six or eight pounds ... I were in Asda just getting a couple of bits for the weekend, for when [daughter] come, and I spoke to her on the phone and she said 'dad, oh will you get me some cheese?' But cheese is like, it can be like $£ 2$ a block and that, so I pinched it because I thought she wanted it but I couldn't afford to buy it. (James, W1)

Following people longitudinally, as welfare reforms took effect, it was possible to track the struggle to get by over time, and to observe how a continued effort to manage on a very low-income sometimes had a negative effect on individuals' mental health and capacity to cope with a day-to-day life of poverty. Chloe, a single parent who was migrated onto JSA and then sanctioned, reflected on the impact of her ongoing experience of poverty and welfare reform:

We're paupers, we're so poor. It's like we're living in - you know where you see all these adverts - please feed our children - feed my bloody children ... Me Dad asked me if I were on drugs the other day, and I said, 'No.' He said I'm looking right withdrawn in face. I said, 'Dad, I am stressed, you have to have money to get drugs, Dad.' So at the end of the day, no, it's stress, can't cope. (Chloe, W3)

Individuals described a chronic state of insecurity and uncertainty linked to ongoing welfare reform, as well as an associated fear about what the future might bring in terms of further benefit changes. This was particularly marked for those in receipt of disability benefits, who were often waiting for the outcomes of benefit reassessments, or anticipating a future reassessment, which often came soon after their eligibility had been decided.

It puts a lot of stress on [me] ... I think about it all the time ... And I'm not my own judge and jury, so what I'm eligible for ... it's in somebody else's hands. So ... you think what are you going to do? (Jim, W1)

The consequences of the extended welfare conditionality regime and the increased length and severity of sanctions meant that some individuals were having their social rights of citizenship completely curtailed, when they are assessed as failing to comply with the conditions of social welfare receipt. This was a common occurrence for Adrian, who was sanctioned several times during the course of the study. While often disputing the reasons for his sanctions, or being unclear as to why a sanction had been deemed appropriate, Adrian vividly illustrated the negative impacts of the loss of income. He described how being unable to eat properly left him 'skinny and everything, [I] look proper ill' (W1), and, in his second interview, after being on a sanction for three months explained:

I've lost a lot of weight because of it. That's really put me down ... I'm having like one, one and a half meals a day. (Adrian, W1)

In an effort to manage while being sanctioned, Adrian would visit food banks, occasionally shoplift food and volunteer at a homeless hostel where he was provided with free meals. Reflecting on the impact of sanctions, Adrian concluded: 
Say my life in the last year and a half, everything that's gone on. If I just take everything out that's gone on apart from the benefits, the benefits issue and just leave that there. I'd call it hell. (Adrian, W3)

The lived experiences for the individuals interviewed suggest that many of those whom poverty and welfare reform directly affect are being denied even Marshall's more minimalist definition of social rights, a 'modicum of economic welfare and security' (1950: 8). Changes to the benefits system are routinely causing entrenched and severe poverty (Oxfam, 2012), which has both negative material and symbolic impacts.

Experiencing chronic poverty undermines individuals' capacity to participate in everyday life and society, with a lack of income serving as a direct barrier to various forms of engagement and participation (Dean and Melrose, 1999; Gaventa, 2002). Cath described how she felt unable to attend a mental health support group as it met at the local museum café:

I know I bang on about money, but with meeting in a place where a cup of tea's $£ 1.75$. I want a hundred tea bags and two pints of milk for that. (Cath, W1)

Family occasions, meals out and Christmas were often associated with dread, anxiety and worry, given the extra expenditure they entailed. Participants often viewed Christmas and birthdays as particular flash points, when the pressure to buy presents and cook special meals became unmanageable:

It's horrible [thinking about Christmas]. I'm not looking forward to Christmas this year at all. I'm really not because I haven't got any money to get anyone anything ... But I just don't like the thought of it being Christmas and not [being able to] actually give them [gifts]. (Sharon, W2)

For the individuals in this study, social rights of citizenship provided relatively little in terms of financial security, making it increasingly difficult for them to obtain an 'equality of status' with their fellow citizens. The growth in voluntary, charitable forms of welfare provision, such as food banks (Garthwaite, 2016), is indicative of the extent to which formal social rights today fail to provide the basic necessities for so many of Britain's citizens. The social rights of citizenship are - of course - today also increasingly conditional on state-defined activities.

\section{Welfare conditionality and conditioning}

Over recent years, welfare conditionality has become the policy tool to encourage, enable and ultimately compel individuals to behave as responsible, hard-working citizens - most often by engaging in the formal labour market. The participants in this study lived with the day-to-day consequences of 'ubiquitous conditionality' (Dwyer and Wright, 2014), and experienced the impact of particular welfare reforms designed to incorporate more and more of the 'inactive welfare dependant' population into the conditionality regime. While the full range of responses to conditionality cannot be reported here, it is vital to highlight key themes of particular relevance to social citizenship and questions of in/exclusion. Importantly, for many of the participants, conditionality was experienced as a controlling, 
paternalistic intervention, which left them feeling dehumanised, with their own societal contributions devalued and undermined.

Susan, a single parent, described how she felt the benefit system operated:

It's not a good thing to see us [claimants]. It's like if I gave you food but then kept telling you; 'you don't eat it like that, you've got to eat it like this.' I don't like it. (Susan, W2)

Her emphasis on the social control implicit in the conditionality regime was shared by James:

It's like when you're on benefits, they're controlling what you do and when you do them. You haven't got your own mind, you've got to do everything by what they say. And sometimes you don't want to. (James, W1)

For those in receipt of out-of-work benefits, state support is tied to a reduction in individual freedom and liberty, and the treatment of claimants as belonging to deficit populations whose behaviour is deemed to require paternalistic interventions, and social control and correction.

In this study, there were also occasions where the conditional obligations the government were seeking to impose on claimants interfered with and compromised the duty and obligations individuals felt as parents, with this a notable example of how conditionality can undermine individuals' capacity to make their own choices about what being a 'good citizen' entails. James described being forced to attend the Work Programme, even when it clashed with legal appointments relating to his battle to become residential parent for his seven year old daughter:

I believe going to court for [my daughter], and fighting that case, that is really important to me and I need to go there before I go to [Work Programme], so they should take that sort of thing into consideration instead of just saying, 'Listen, that's your appointment, if you don't turn up, skip ...' That's how they approach it. (James, W3)

However, at the same time as there was considerable resistance to conditionality, there were also instances where participants implicitly welcomed it, suggesting that the compulsion and support might help in their efforts to secure paid employment. Karen described how she felt both excited and frightened about being moved onto JSA and the extra conditions this would involve:

It's good to get out of the house, not to be stuck at home all day, but at the same time I'm scared to get out there and do it all again ... It's going to push me to get a job, but at the same time it's pushing me too fast. (Karen, W2)

While conditionality was met with mixed reactions, what was often apparent was how far individuals were self-governing as they sought to secure paid employment, where it was a realistic objective. Indeed, participants frequently spoke about the efforts they were taking to find work, and how these efforts were framed by and partially driven by a desire to leave reliance on benefits behind and the stigma with which this was associated (Patrick, 2015). Participants often accepted exploitative and badly paid jobs, as they argued these were preferable to being on out-of-work benefits. Josh was employed 
at a corner shop on a fixed rate of pay of $£ 80$ per week for 35 hours work. He accepted this was substantially less than he was entitled to on the national minimum wage but reflected:

It's all I can get at the minute. I can't seem to find anywhere else. I keep applying and nowhere seems to want me so I'll take what I can get really. (Josh, W3)

Showing an internalisation of the stigma of benefit receipt, Sam described how she was desperate to find a job so she could stop feeling like a 'scrounger' (Patrick, 2014). Sam described herself as a 'scrounger' in two of the three interviews, reflecting an internalisation of the dominant narrative that problematises 'welfare' and those who rely upon it. After the study had finished, Sam did manage to find a job in retail with just 12 hours' work guaranteed per week. The income she received did not enable her to escape poverty, and she remained reliant on social welfare via Housing Benefit.

Arguably, there is emerging evidence of a shift from conditionality to conditioning (Dwyer and Ellison, 2009), such that individuals are self-governing, even engaging in do-it-yourself social policy (Klein and Millar, 1995), as they seek to fulfil the contemporary requirements of the dutiful citizen. Certainly, there was considerable evidence of individuals internalising the stigma of benefits receipt and then actively seeking to leave benefits and find paid employment, with the threat of sanctions and conditionality a perhaps unnecessary additional spur. This is perhaps symptomatic of a climate in which social problems and structural issues are increasingly conceptualised as individual problems, representative of individual failings and shortcomings, what Ferge (1997) describes as an 'individualization of the social'.

There is a need for more policy and academic attention directed towards the ways in which conditionality and conditioning mesh together, and there is scope to explore how far and in what ways benefits stigma is here actually operating as a tool of governance that promotes and encourages individuals to behave in ways that the state would like and has come to expect (Tyler, 2014). In particular, there is a need to explore whether the rationale for conditionality is undermined by the signs of a 'welfare conditioning' in how individuals themselves live with and respond to out-of-work benefits receipt. There is also scope for research which more fully engages with the ways in which conditionality can actually undermine individuals' capacity to be self-governing individuals, given the narrow and strict conditions it so often imposes. Finally, it is important to try and locate the root of any such 'welfare conditioning' more precisely. This could include explorations of whether and how far individuals are orientating themselves towards paid employment because of the power and persuasiveness of government rhetoric and the stigma associated with benefits receipt, or whether instead this is simply reflective of their own work-related aspirations and the importance they themselves attach to engagement in the formal labour market.

\section{Conclusion}

In common with previous studies (Lister, 1990; Dean and Melrose, 1999; Dwyer, 2010), this article has illustrated the extent to which poverty and benefit receipt are associated with a fractured citizenship status, with recent welfare reforms creating 
pervasive insecurity and denying to so many even a 'modicum of economic welfare and security' (Marshall, 1950). The dominant citizenship narrative from above suggests that welfare reform and the expansion and intensification of conditionality will help deliver social inclusion (and thus full citizenship) for those currently reliant on out-ofwork benefits, characterising compulsion and conditions as paternalistic tools which will help and support individuals to transform their own lives and become independent, dutiful, hardworking citizens. This Social Integrationist Discourse (Levitas, 1998) allowed David Cameron to suggest that the broader reform approach is part of steps to deliver security for all. However, such an argument neglects the extent to which the denial and curtailing of the social rights of citizenship is instead leading to a 'normalization of social insecurity' (Wacquant, 2010), with promises of societal inclusion concealing the social and citizenship exclusion that poverty and welfare reform can cause.

In the current context, citizenship is increasingly operating as a form of social control, a subversion of its original emancipatory intent (Clarke, 2005; Flint, 2009). Conditionality, compulsion and a pervasive benefits stigma work together to create a regime of governance which problematises, objectifies and then seeks to correct the behaviours of certain groups within society, with out-of-work benefit claimants a particular target as an abject population (Tyler, 2014). This research found a particular predominance of individuals critiquing their own benefit claiming behaviours and actively seeking to correct this by seeking paid employment, where it was a realistic option (and not always with success) (Patrick, 2014, 2015). There is therefore a need to more fully explore the extent to which conditionality now operates alongside a form of conditioning (Dwyer and Ellison, 2009), which sees individuals self-govern and critique their own behaviour as they seek to fulfil the contemporary requirements of the dutiful citizen. This conditioning could partly result from an increasing acceptance of conditionality as governing benefit entitlement, as its widespread application sees it become normalised and experienced as unexpected and inevitable, if not unproblematic. The ways in which the resultant conditioning can be particularly difficult for those who are simply unable to participate in paid employment - for example, due to caring responsibilities or health issues and/or impairments - and the consequences of this for affected individuals would also merit further attention.

Finally, there is a pressing need to reconsider the role that social citizenship can play in calls for more meaningful societal inclusion, and in efforts to ensure that all of society is granted a degree of security, something which Cameron may himself have proclaimed to aspire to, but which his policies did not in fact seem to deliver. If social citizenship's emancipatory potential is to be reclaimed, which effectively requires a challenge to its current operation as a form of governmental societal control, it will be vital to first reanimate and rethink what a more progressive and socially democratic conceptualisation of citizenship might entail. Fundamental to this would be an emphasis on social security, understood as a challenge and corrective to the pervasive insecurity that currently predominates for so many, alongside a focus on participation rights, which should sit alongside T. H. Marshall's social, political and civil rights (Marshall, 1950; Lister, 1998; Gaventa, 2002). Access to resources that enable individuals to feel able to participate in their community and in society are critical if citizenship is to deliver a meaningful status (Gaventa, 2002; Lister, 2003). Further, academics, campaigners and politicians all need to pay far more attention to the everyday worlds of citizenship, perhaps in an effort to develop what Duffy describes as a notion of 'everyday citizenship' (Duffy, 
2016) that is grounded in real human experiences and aspirations, rather than empty rhetoric. Much of social citizenship's conceptual power lies in the fact that it is 'imparfaite' and unfinished, constantly being reworked and reimagined both in government narrative and discourse, and in experiences and responses to the state by citizens themselves (Balibar, 2001, cited in Clarke et al., 2014). There is thus a key role for academics to play in shining a critical lens on the ways in which social citizenship is being co-opted from above as a tool of governance, but also in how it is lived and experienced from below. It is important also to explore how it might be revisioned in ways that could deliver greater social inclusion and solidarity for all.

\section{Acknowledgements}

The author is indebted to the participants in this study, who gave up their time and let the author into their homes to share their experiences of social security receipt and welfare reform. The author is also grateful to the Economic and Social Research Council for funding the research reported here. She would also like to thank the anonymous reviewers as well as Daniel Edmiston, Kayleigh Garthwaite and Nick Ellison for their feedback and comments on earlier versions of this paper.

\section{Notes}

1 W1 denotes first wave of interviews, W2 second wave, and W3 third wave.

\section{References}

Bailey, N. (2016) 'Exclusionary employment in Britain's broken labour market', Critical Social Policy, 36, 82-103.

Beatty, C. and Fothergill, S. (2016) The Uneven Impact of Welfare Reform: The Financial Losses to Places and People, Sheffield, Centre for Regional Economic and Social Research, Sheffield Hallam University with Oxfam and Joseph Rowntree Foundation.

Cameron, D. (2011) 'Prime Minister's speech on Welfare Reform Bill', 17 February, Prime Minister's Office, London, https://www.gov.uk/government/speeches/pms-speech-on-welfare-reform-bill [accessed 21/02/2011].

Cameron, D. (2016) 'Prime Minister's speech on life chances', HM Government, London, https://www.gov.uk/government/speeches/prime-ministers-speech-on-life-chances [accessed 01/02/2016].

Clarke, J. (2005) 'New Labour's citizens: activated, empowered, responsibilized, abandoned?', Critical Social Policy, 25, 447-63.

Clarke, J., Coll, K., Dagnino, E. and Neveu, C. (2014) Disputing Citizenship, Bristol, Policy Press.

Crabb, S. (2016) 'Transforming lives through welfare and work', speech to the Early Intervention Foundation by Rt Hon. Stephen Crabb MP, 12 April, Department for Work and Pensions, London, https://www.gov.uk/government/speeches/transforming-lives-through-welfare-and-work [accessed 21/04/2016].

Daly, M. and Kelly, G. (2015) Families and Poverty: Everyday Life on a Low Income, Bristol, Policy Press.

De Agostini, P., Hills, J. and Sutherland, H. (2015) Were We Really All in It Together? The Distributional Effects of the 2010-2015 UK Coalition Government's Tax-Benefit Policy Changes: An End-of-term Update, London, CASE, London School of Economics and Political Science.

Dean, H. and Melrose, M. (1999) Poverty, Riches and Social Citizenship, Basingstoke, Macmillan. 
Department for Work and Pensions (DWP) (2012) Welfare Reform Act 2012, London: Department for Work and Pensions, http://www.dwp.gov.uk/policy/welfare-reform/legislation-and-key-documents/ welfare-reform-act-2012/ [accessed 06/07/2012].

Department for Work and Pensions (DWP) and Department for Education (2011) A New Approach to Child Poverty: Tackling the Causes of Disadvantage and Transforming Families' Lives, Cm 8061, London: HM Government.

Dole Animators (2013) Dole Animators, www.doleanimators.org [accessed 08/07/2013].

Duffy, S. (2016) Citizenship and the Welfare State: The Need for Roots, Sheffield, The Centre for Welfare Reform.

Dwyer, P. (2010) Understanding Social Citizenship: Themes and Perspectives for Policy and Practice, Bristol: Policy Press.

Dwyer, P. and Ellison, N. (2009) 'Work and welfare: the rights and responsibilities of unemployment in the UK', in M. Giugni (ed.), The Politics of Unemployment in Europe: Policy Responses and Collective Action, Farnham: Ashgate Publishing.

Dwyer, P. and Wright, S. (2014) 'Universal credit, ubiquitous conditionality and its implications for social citizenship', Journal of Poverty and Social Justice, 22, 27-35.

Ferge, Z. (1997) 'The changed welfare paradigm: the individualization of the social', Social Policy and Administration, 31, 20-44.

Flint, J. (2009) 'Subversive subjects and conditional, earned and denied citizenship', in M. Barnes and D. Prior (eds.), Subversive Citizens: Power, Agency and Resistance in Public Services, Bristol: Policy Press.

Garthwaite, K. (2016) Hunger Pains: Life Inside Fodbank Britain, Bristol: Policy Press.

Gaventa, J. (2002) 'Introduction: exploring citizenship, participation and accountability', IDS Bulletin, 33.

Henwood, K., Neale, B. and Holland, J. (2012) 'Researching lives through time: an introduction to the timescapes approach', Qualitative Research, 12, 4-15.

Klein, R. and Millar, J. (1995) 'Do-it-yourself social policy: searching for a new paradigm?', Social Policy and Administration, 29, 303-16.

Lansley, S. and Mack, J. (2015) Breadline Britain: The Rise of Mass Poverty, London: OneWorld Publications.

Levitas, R. (1998) The Inclusive Society? Social Exclusion and New Labour, Basingstoke, Macmillan.

Lister, R. (1990) The Exclusive Society: Citizenship and the Poor, London, Child Poverty Action Group.

Lister, R. (1998) 'Citizens in action: citizenship and community development in Northern Ireland context', Community Development Journal, 33, 226-35.

Lister, R. (2003) Citizenship: Feminist Perspectives, 2nd edn, Basingstoke: Palgrave.

Lister, R. (2007) 'Inclusive citizenship: realizing the potential', Citizenship Studies, 11, 49-61.

Lister, R. (2011) 'The age of responsibility: social policy and citizenship in the early 21 st century', in C. Holden, M. Kilkey and G. Ramia (eds.), Social Policy Review, 23, Analysis and Debate in Social Policy, Bristol: Policy Press.

Marshall, T. H. (1950) Citizenship and Social Class: And Other Essays, Cambridge: University Press.

McKay, S. and Rowlingson, K. (2011) 'Social security and welfare refom', in H. Bochel (ed.), The Conservative Party and Social Policy, Bristol: Policy Press.

Neale, B. and Hanna, E. (2012) 'The ethics of researching lives through time', in B. Neale and K. Henwood (eds.), Timescapes Method Guide Series, Leeds: Timescapes.

Osborne, G. (2010) 'Our tough but fair approach to welfare', Chancellor's speech to the Conservative Party Conference, 4 October, http://www.conservatives.com/News/Speeches/2010/10/ George_Osborne_Our_tough_but_fair_approach_to_welfare.aspx [accessed 04/10/2010].

Oxfam (2012) The Perfect Storm: Economic Stagnation, the Rising Cost of Living, Public Spending Cuts, and the Impact on UK Poverty, Oxford: Oxfam.

Patrick, R. (2014) 'Working on welfare: findings from a qualitative longitudinal study into the lived experiences of welfare reform in the UK', Journal of Social Policy, 43, 705-25. 
Patrick, R. (2015) 'Irresponsible citizens? The lived experiences of welfare reform', Doctoral thesis, University of Leeds.

Shildrick, T., MacDonald, R., Webster, C. and Garthwaite, K. (2012) Poverty and Insecurity: Life in Low-pay, No-pay Britain, Bristol: Policy Press.

Tyler, I. (2014) From 'The Shock Doctrine' to 'The Stigma Doctrine', http://socialabjection.wordpress.com/ 2014/05/12/from-the-shock-doctrine-to-the-stigma-doctrine-imogen-tyler/ [accessed 03/12/2014].

Wacquant, L. (2010) 'Crafting the neoliberal state: workfare, prisonfare, and social insecurity', Sociological Forum, 25, 197-220. 